УДК 622.276

\title{
ОЦЕНКА ОХВАТА ПЛАСТА СИСТЕМОЙ РАЗРАБОТКИ С ПОМОЩЬЮ РАДИУСА ДРЕНИРОВАНИЯ СКВАЖИН
}

\author{
Поплыгин Владимир Валерьевич1, \\ poplygin@bk.ru
}

\author{
Соколов Александр Владимирович1, \\ sokolovalexandr.vladimirovich@gmail.com \\ 1 Пермский национальный исследовательский политехнический университет, \\ Россия, 616990, г. Пермь, Комсомольский пр., 29.
}

\begin{abstract}
Актуальность исследования. В гидродинамических симуляторах фильтрация фрлюидов описывается с помощью законов сохранения массы, в результате чего может оказаться, что значительная часть объекта разработки вовлечена в процесс дренирования. Данный подход может не вполне корректно оценить область притока жидкости к добывающей скважине. Зоны притока жидкости к скважине (зоны дренирования) часто схематизируют в виде концентричной к скважине окружности с радиусом, равным половине расстояния между забоями скважин. Данный подход не учитывает различие линий тока, границы пласта, его неоднородность и другие фракторы. Значение радиуса дренирования особенно изменчиво в карбонатных коллекторах при изменении пластового давления. Достоверная оценка размера зоны дренирования скважин позволит более точно оценить степень охвата залежи разработкой, особенно в карбонатном коллекторе.

Цель: исследовать возможность охвата залежи нефти системой разработки с помощью оценки фактических радиусов дренирования скважин; определить наиболее эфрфективные технологии увеличения радиуса дренирования скважин.

объект: Башкирская залежь на месторождении нефтти в Соликамской депрессии. Средняя обводненность продукции скважин на залежи составляет 39,2 \%. На залежи отмечается существенная зависимость фрильтрационных параметров горных пород от пластовых и забойных давлений.

Методы: определение значений коэффициентов проницаемости и пьъезопроводности на основе обработки результатов гидродинамических исследований.

Результаты. На текущий момент времени залежь нефти охвачена разработкой по площади на 40 \%. На радиус дренирования скважин существенное влияние оказывает коэффрициент проницаемости. На рассматриваемом объекте отмечена сильная взаимосвязь между коэфффициентом проницаемости и энергетическим состоянием залежи. Понижение значения радиусов дренирования скважин может существенно уменьшить охват залежи системой разработки и увеличить сроки выработки извлекаемых запасов нефти. На рассматриваемом объекте разработки наиболее эфффективные методы увеличения радиусов дренирования скважин - кислотные гидроразрывы и комбинированные с другими технологиями кислотные обработки.
\end{abstract}

\section{Ключевые слова:}

Залежь нефти, радиус дренирования, проницаемость, забойное давление, нефтеотдача.

\section{Введение}

В настоящее время плотность запасов нефти на залежи определяется с помощью гидродинамических симуляторов. Наиболее распространены модели black oil, в которых численно решаются системы уравнений, описывающих трехфазное движение флюидов в пористой среде. Фильтрация флюидов описывается с помощью законов сохранения массы, в результате чего может оказаться, что значительная часть объекта разработки вовлечена в процесс дренирования. Однако данный подход может не вполне корректно оценить область притока жидкости к добывающей скважине. Зоны притока жидкости к скважине (зоны дренирования) часто схематизируют в виде концентричной к скважине окружности с радиусом, равным половине расстояния между забоями скважин. Данный подход не всегда является достоверным, поскольку не учитывает различие линий тока, границы пласта, его неоднородность и другие факторы. Значение радиуса дренирования особенно изменчиво в карбонатных коллекторах при изменении пластового давления. На сегодняшний день доля разрабатываемых объектов, приуроченная к карбонатным сложнопостроенным залежам в Пермском крае, составляет более 50 \%. Разработка таких залежей осложнена отложениями асфальтенов, смол и парафинов, деформациями, выделением в свободную фазу растворенного в нефти газа и др., что в конечном итоге может сказаться на уровнях добычи нефти [1-9].

Достоверная оценка размера зоны дренирования скважин позволит более точно определить степень охвата залежи разработкой, особенно в карбонатном коллекторе.

\section{Объект исследования}

В Пермском крае значительная часть продуктивных карбонатных коллекторов приурочена к Соликамской депрессии [10]. Рассмотрим башкирский объект разработки одного из типичных месторождений указанной тектонической структуры. Промышленная разработка залежи началась в 1998 г. Основные геолого-физические параметры и показатели разработки залежи приведены в таблице.

Из таблицы следует, что залежь содержит легкую газонасыщенную нефть. Горные породы характеризуются высокой проницаемостью и расчлененностью. Из-за позднего ввода системы поддержания пластового давления текущее давление в пласте существенно ниже начальной величины. В специальной литературе отмечена существенная зависимость фильтрационно-емкостных 
параметров месторождений от энергетического состояния залежей [11-14]. Согласно [15], текущие фильтрационные параметры рассматриваемой залежи понижены относительно начальных величин в среднем на $20 \%$. Так как

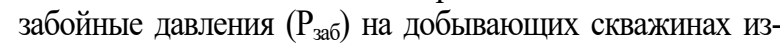
меняются в пределах 2,1...10,7 МПа и существенно ниже давления насыщения $\left(\mathrm{P}_{\text {нас) }}\right)$, фильтрация дополнительно осложнена выделяющимся из нефти в свободную фазу газом, а коэффициенты проницаемости и пьезопроводности существенно снижены (рис. 1).

Таблица. Основные геолого-физические параметры и показатели разработки залежи

Table. Main geological and physical parameters and indicators of deposit development

\begin{tabular}{|c|c|c|}
\hline $\begin{array}{r}\text { Параметр } \\
\text { Parameter } \\
\end{array}$ & $\begin{array}{l}\text { Ед. измер. } \\
\text { Units } \\
\end{array}$ & $\begin{array}{c}\text { Значение } \\
\text { Value }\end{array}$ \\
\hline $\begin{array}{l}\text { Проницаемость по керну } \\
\text { Core permeability }\end{array}$ & $\begin{array}{c}\text { мКм }^{2} \\
\text { micron }^{2}\end{array}$ & 0,134 \\
\hline $\begin{array}{l}\text { Коэффициент песчанистости } \\
\text { Sandiness coefficient }\end{array}$ & \multirow{2}{*}{$\begin{array}{c}\text { доли ед. } \\
\text { unit fraction }\end{array}$} & 0,35 \\
\hline $\begin{array}{l}\text { Коэффициент расчлененности } \\
\text { Number of permeable intervals }\end{array}$ & & 6,1 \\
\hline $\begin{array}{l}\text { Вязкость нефти в пластовых условиях } \\
\text { Reservoir oil viscosity }\end{array}$ & $\begin{array}{l}\mathrm{м} \Pi \mathrm{a} * \mathrm{c} \\
\mathrm{mPa} * \mathrm{~s}\end{array}$ & 2,41 \\
\hline $\begin{array}{l}\text { Начальное пластовое давление } \\
\text { Initial reservoir pressure }\end{array}$ & $\begin{array}{l}\mathrm{M \Pi а} \\
\mathrm{MPa}\end{array}$ & 15,1 \\
\hline $\begin{array}{l}\text { Газонасыщенность пластовой нефти } \\
\text { Gas saturation }\end{array}$ & $\begin{array}{l}\mathrm{M}^{3} / \mathrm{T} \\
\mathrm{m}^{3} / \mathrm{t}\end{array}$ & 53,8 \\
\hline Давление насыщения/Saturation pressure & Мпа/МРа & 13,58 \\
\hline Отбор от НИЗ/Оil recovery & \multirow{2}{*}{$\%$} & 51,3 \\
\hline Обводненность/Water cut & & 39,2 \\
\hline
\end{tabular}

\section{Оценка радиусов дренирования скважин}

В специальной литературе приведена формула для оценки радиусов дренирования скважин [16]:

$$
R_{k}=\sqrt{\pi \varkappa t},
$$

где $x$ - пьезопроводность $\mathrm{m}^{2} / \mathrm{c} ; t$ - время полного восстановления давления в скважине, с.

Для скважин рассматриваемой залежи на основании результатов гидродинамических исследований выполнено определение параметров для вычисления пьезопроводности, а также с помощью метода произведения - время полного восстановления давления в скважине. Далее по формуле (1) определены радиусы дренирования скважин

Выполнена оценка влияния на значение радиусов дренирования скважин основных геологотехнических параметров. Для башкирской залежи Озерного месторождения отмечено, что наибольшее влияние на радиус дренирования скважин оказывают значения коэффициентов пъезопроводности, проницаемости и энергетического состояния (рис. 2, 3).

Снижение радиуса дренирования при уменьшении пластовых и забойных давлений можно объяснить деформациями коллектора и снижением фазовой проницаемости по жидкости.

\section{Оценка охвата пласта системой разработки}

На карту плотности запасов нанесены значения радиусов дренирования скважин (рис. 4).

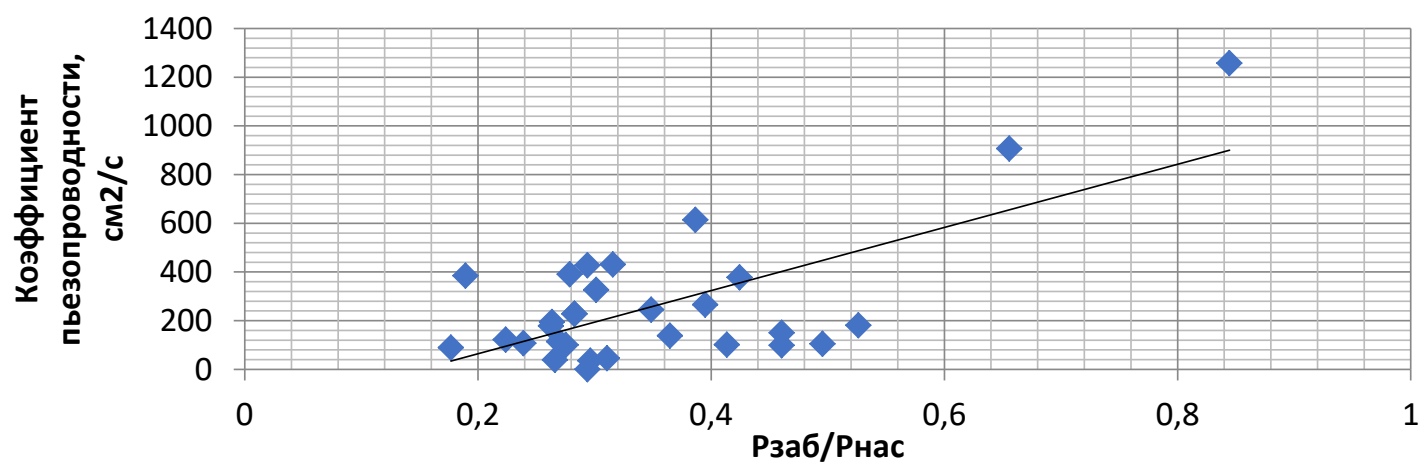

Pис. 1. Зависимость коэффициента пьезопроводности от относительного забойного давления

Fig. 1. Dependence of the piezoconductivity coefficient on the relative bottomhole pressure

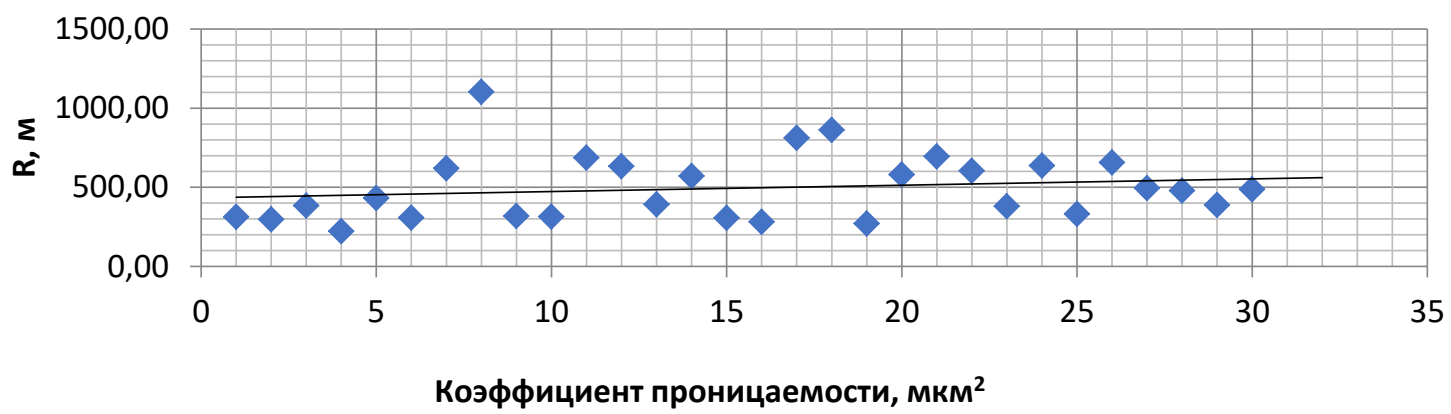

Puc. 2. Зависимость R от коэффициента проницаемости призабойной зонь

Fig. 2. $R$ dependence on the permeability coefficient of the bottomhole zone 


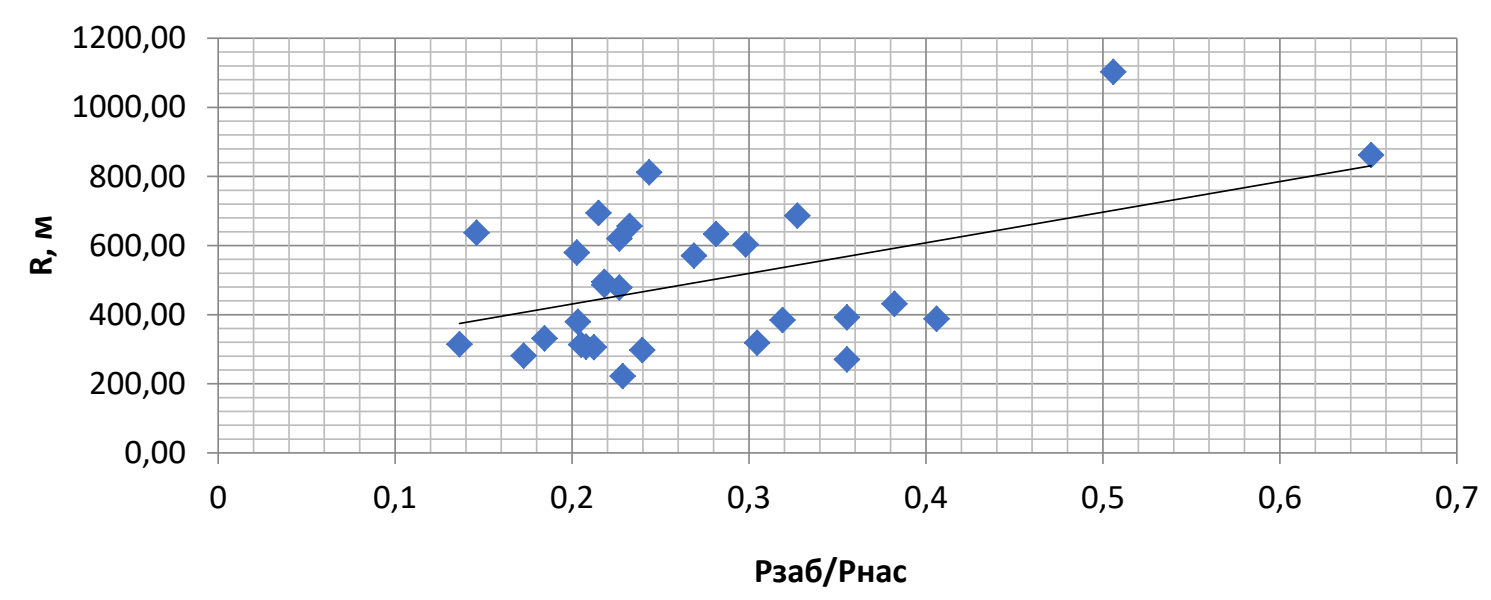

Pис. 3. Зависимость R от относительного забойного давления

Fig. 3. $R$ dependence on the relative bottomhole pressure

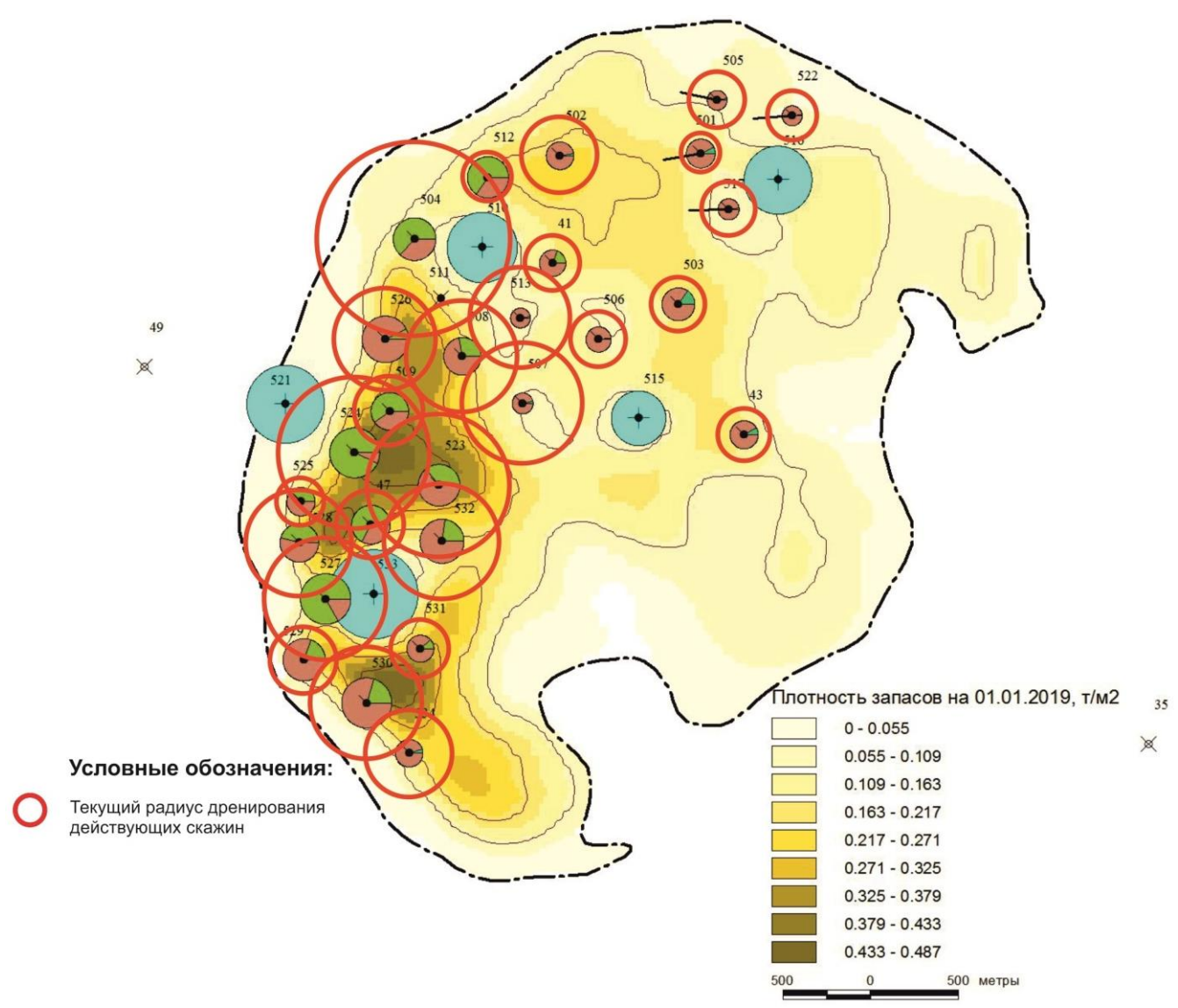

Pис. 4. Карта плотности запасов с радиусами дренирования скважин

Fig. 4. Map of stock density with well drainage radii

На объекте имеются участки, не вовлеченные в разработку. Скважины восточной части залежи характеризуются малыми значениями радиуса дренирования, что связано с худшими значениями фильтрационных параметров по сравнению с западной частью залежи. Участок в северной части залежи между скважинами №№ 502, 41, 501, 503, 517 не охвачен дренированием. Также не охвачен разработкой участок между скважинами №№ 503, 43, однако пласт Бш3 на данном участке насыщен водой и возможно обводнение скважины, то же можно сказать о участке к юго-востоку от скважин №№ 531, 530, 524, участок характеризуется хорошими запасами, но пласт Бш3 на данном участке насыщен водой. Участок к востоку от скважины № 503 и южнее скважины № 516 на 500700 м не вовлечён в разработку и обладает невысокой плотностью запасов.

Общий охват залежи системой добывающих скважин на текущую дату составляет около $40 \%$ от площади всей залежи внутри водонефтяного контакта. 
Влияние на радиус дренирования геолого-технических мероприятий

Для определения влияния геолого-технических мероприятий (ГТМ) на R рассмотрена история проведения ГТМ на залежи и определены $\mathrm{R}$ до и после мероприятий. Среднее увеличение $\mathrm{R}$ по каждому виду ГТМ представлено на рис. 5.

Наибольшая эффективность работ получена после кислотного гидроразрыва пласта [17]. Результативность комбинированной кислотной обработки, проведенной совместно с другим мероприятием, выше, чем у простой кислотной обработки (1,7 и 1,59 соответственно). Для кислотных обработок без дополнительных мероприятий была сравнена эффективность составов Флаксокор-210 и ДН-9010, составы использовались 8 и 5 раз соответственно. Эффективность состава Флаксокор-210 оказалась выше, среднее увеличение радиуса дренирования равно 1,69 , а для состава ДН-9010 среднее увеличение равно 1,41. В целом мероприятия с кислотным воздействием являются наиболее эффективными для карбонатных коллекторов [18-20].

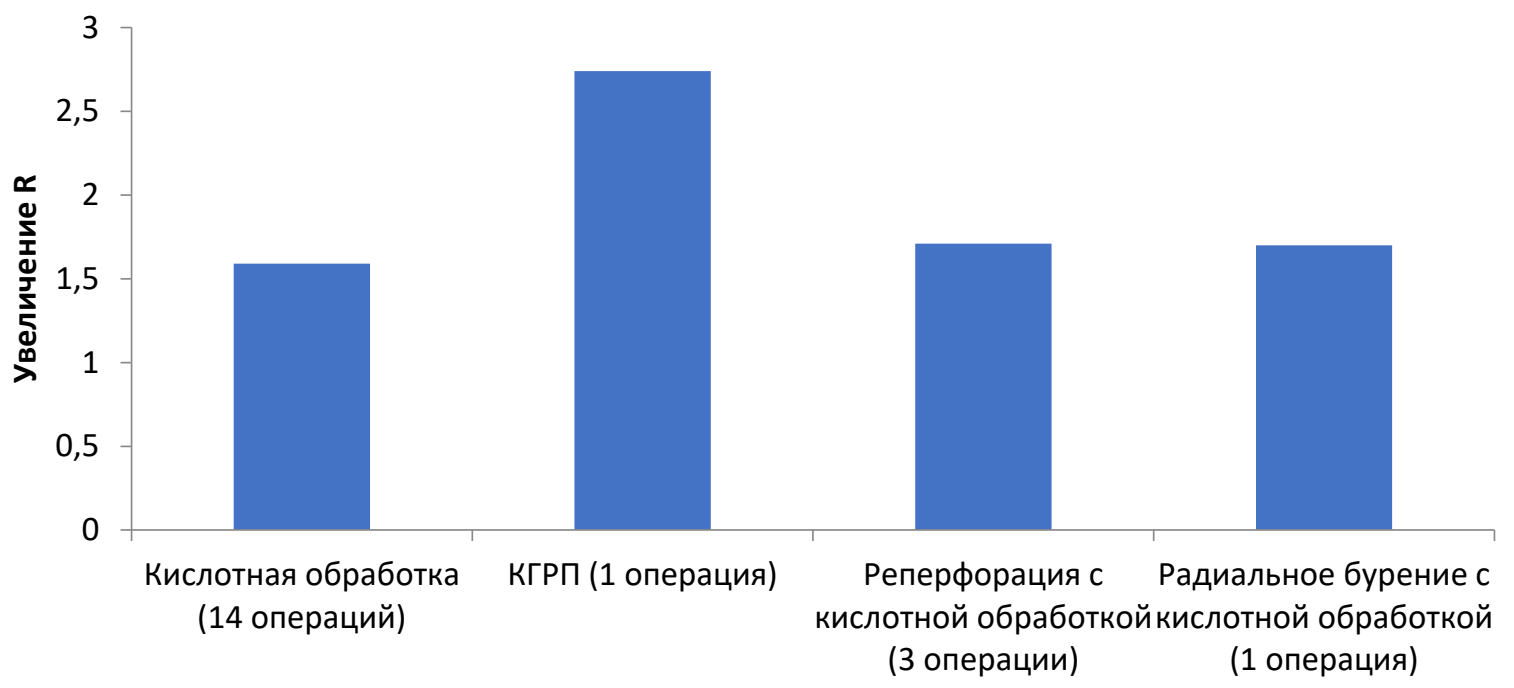

Pис. 5. Среднее увеличение радиуса дренирования после ГТМ

Fig. 5. Average increase in drainage radius after geological and technical measures

\section{Выводы}

1. Определение радиуса дренирования для добывающих скважин позволяет оценить охват системой разработки залежи нефти. На текущий момент времени залежь нефти охвачена разработкой по площади на $40 \%$.

2. На радиус дренирования скважин существенное влияние оказывает коэффициент проницаемости. На рассматриваемом объекте отмечена сильная взаимосвязь между коэффициентом проницаемости и энергетическим состоянием залежи. При снижении забойных давлений происходит уменьшение коэффициента проницаемости из-за деформаций коллектора и выделения в свободную

\section{СПИСОК ЛИТЕРАТУРЫ}

1. Sun H., Vega S., Tao G. Analysis of heterogeneity and permeability anisotropy in carbonate rock samples using digital rock physics // Journal of Petroleum Science and Engineering. 2017. - V. 156. - P. 419-429.

2. Hosseini E. Experimental investigation of effect of asphaltene deposition on oil relative permeability, rock wettability alteration, and recovery in WAG process // Petroleum Science and Technology. - 2019. - V. 37. - Iss. 20. - P. 2150-2159.

3. Moradi M., Shamloo A., Dezfuli A.D. A sequential implicit discrete fracture model for three-dimensional coupled flowgeomechanics problems in naturally fractured porous media // фазу растворенного в нефти газа, что ведет и к уменьшению радиуса дренирования скважин. Понижение значения радиусов дренирования скважин может существенно уменьшить охват залежи системой разработки, что, в свою очередь, приведет к увеличению сроков выработки извлекаемых запасов нефти.

3. На рассматриваемом объекте разработки наиболее эффективными методами увеличения радиусов дренирования скважин являются кислотные гидроразрывы и комбинированные с другими технологиями кислотные обработки.

Исследование выполнено за счет гранта Российского научного фонда (проект № 19-79-10034).

Journal of Petroleum Science and Engineering. - 2017. - V. 150. P. 312-322.

4. Coupled geomechanics and pore confinement effects for modeling unconventional shale reservoirs / Y. Xiong, P.H. Winterfeld, Y.-S. Wu, Z. Huang // Unconventional Resources Technology Conference. Denver, United States, 2014. DOI: 10.15530/urtec-2014-1923960

5. Fluid flow numerical experiments of faulted porous carbonates, Northwest Sicily (Italy) / M. Antonellini, A. Cilona, E. Tondi, M. Zambrano, F. Agosta // Marine and Petroleum Geology. - 2014. V. 55. - P. 186-201.

6. Wilson T.H., Smith V., Brown A. Developing a model discrete fracture network, drilling, and enhanced oil recovery strategy in an 
unconventional naturally fractured reservoir using integrated field, image log, and three-dimensional seismic data // AAPG Bulletin. 2015. - V. 99. - Iss. 4. - P. 735-762.

7. Feng Z., Shuhong W. Fully coupled hydromechanical flow simulation of water-induced dynamic fractures in low-permeability reservoirs // International Field Exploration and Developmen Conference, IFEDC 2016. - Beijing, China, 2016. - Iss. CP706.

8. Повышение эффективности разработки месторождений углеводородов на основе комплексных геомеханических исследований / Ю.А. Кашников, С.Г. Ашихмин, Д.В. Шустов, С.Ю. Якимов, А.Э. Кухтинский // Нефтяное хозяйство. 2019. - № 3. - С. 66-69.

9. Лебединец Н.П. О деформационных изменениях проницаемости трещиноватых коллекторов (в порядке обсуждения) // Нефтяное хозяйство. - 2014. - № 6. - С. 99-101.

10. Гладких Е.А., Хижняк Г.П., Галкин В.И. Влияние фильтрационно-емкостных свойств объектов разработки на величину коэффициента вытеснения нефти в различных геологофизических условиях // Известия Томского политехнического университета. Инжиниринг георесурсов. - 2018. - Т. 329. № 7. - C. 77-85.

11. Mahzari P., Jones A.P., Oelkers E.H. An integrated evaluation of enhanced oil recovery and geochemical processes for carbonated water injection in carbonate rocks // Journal of Petroleum Science and Engineering. - 2019. - V. 181. - Iss. № 106188.

12. Parameters affecting load recovery and oil breakthrough time after hydraulic fracturing in tight oil wells / B. Zanganeh, M. Soroush, J.D. Williams-Kovacs, C.R. Clarkson // Unconventional Resources Conference. - Calgary, Canada, 2015. - № SPE-175941-MS

13. Experimental and analytical core and geomechanical data analysis of a tight oil carbonate formation / A. Islam, A.S. Ziarani, A. Cui, S. Ehlers, B. Schneider // Proceedings. SPE Annual Technical Conference and Exhibition. - Amsterdam, Netherlands, 27-29 October 2014. - V. 6. - P. 4772-4792.
14. Щербаков А.А., Хижняк Г.П., Галкин В.И. Прогнозирование коэффициента продуктивности скважин с боковым стволом (на примере Уньвинского месторождения) // Известия Томского политехнического университета. Инжиниринг георесурсов. -2019 . - Т. 330. - № 5. - С. 93-99.

15. Поплыгин В.В., Уирсигроч М., Павловская Е.Е. Прогнозирование изменения коэффициентов продуктивности скважин в башкирско-серпуховских отложениях месторождений севера Пермского края // Нефтяное хозяйство. - 2016. - № 10. C. $78-81$.

16. Бузинов С.Н., Умрихин И.Д. Гидродинамические методы исследования скважин и пластов. - М.: Изд-во «Недра», 1973. $-248 \mathrm{c}$

17. Продуктивность скважин после кислотных гидроразрывов пласта на Гагаринском и Озерном месторождениях / В.А. Мордвинов, В.В. Поплыгин, Д.Д. Сидоренко, А.Р. Шаймарданов // Нефтяное хозяйство. - 2013. - № 4. - С. 44-45.

18. Jahani N., Haugen B., Berge G. Coupled fluid flow and elastoplastic damage analysis for fractured porous chalk with induced wormhole // International Journal of Rock Mechanics and Mining Sciences. - 2015. - V. 80. - P. 129-136.

19. Эффективность кислотных обработок скважин, эксплуатирующих башкирские отложения на месторождениях Пермского края / Е. Павловская, В.В. Поплыгин, Д.Ю. Иванов, И.Ю. Елисеев // Нефтяное хозяйство. - 2015. - № 3. - С. 28-30.

20. Мартюшев Д.А. Лабораторные исследования кислотных составов для обработки коллекторов, характеризующихся различной карбонатностью и структурой пустотного пространства горных пород // Известия Томского политехнического университета. Инжиниринг георесурсов. - 2018. - Т. 329.№ 4. - C. 6-12.

Поступила 12.03.2020 г.

\section{Информация об авторах}

Поплыгин В.В., кандидат технических наук, доцент кафедры нефтегазовыех технологий Пермского национального исследовательского политехнического университета.

Соколов А.В., инженер ООО «ЛУКОЙЛ-Инжиниринг» «ПермНИПИнефть» в г. Перми. 
UDC 622.276

\title{
ESTIMATION OF A RESERVOIR COVERAGE BY THE DEVELOPMENT SYSTEM USING THE DRAINING WELL RADIUS
}

\author{
Vladimir V. Poplygin', \\ poplygin@bk.ru \\ Aleksandr V. Sokolov', \\ sokolovalexandr.vladimirovich@gmail.com \\ 1 Perm National Research Polytechnic University, \\ 29, Komsomolsky avenue, Perm, 614990, Russia.
}

Relevance of the research. In hydrodynamic simulators, fluid filtration is described using the laws of mass conservation, as a result of which it may turn out that a significant part of the development object is involved in the drainage process. This approach may not quite correctly assess the region of fluid inflow to the producing well. The zones of fluid flow to the well (drainage zones) are often schematized as a circle concentric to the well with a radius equal to half the distance between the bottom of the wells. This approach does not take into account the difference in streamlines, reservoir boundaries, its heterogeneity and other factors. The value of the drainage radius is especially variable in carbonate reservoirs with changes in reservoir pressure. A reliable estimate of the size of the well drainage zone will make it possible to more accurately assess the extent of reservoir development, especially in the carbonate reservoir.

The aim of the research is to investigate the possibility of oil field coverage by the development system by assessing the actual radius of well drainage; to determine the most effective technologies for increasing the radius of well drainage.

Object: Bashkir deposit at the oil field in the Solikamsk depression. The average water cut of well production in the reservoir is $39,2 \%$. There is a significant dependence of rock filtration parameters on reservoir and bottomhole pressures.

Methods: determination of the values of the permeability coefficients and piezoconductivity based on processing the results of hydrodynamic studies.

Results. At the current time, the oil reservoir is for $40 \%$ covered by development. The radius of drainage of wells is significantly affected by the permeability coefficient. At the object under consideration, a strong relationship between the permeability coefficient and the energy state of the reservoir was noted. Reducing the values of well drainage radii can significantly decrease the reservoir coverage by the development system and increase the terms of development of recoverable oil reserves. At the considered development object, the most effective methods for increasing well drainage radii are acid fractures and acid treatments combined with other technologies.

\section{Key words:}

Oil layer, drainage radius, permeability, bottom hole pressure, oil recovery.

The research was financed through the grant of the Russian Science Foundation (project no. 19-79-10034).

\section{REFERENCES}

1. Sun H., Vega S., Tao G. Analysis of heterogeneity and permeability anisotropy in carbonate rock samples using digital rock physics. Journal of Petroleum Science and Engineering, 2017, vol. 156, pp. 419-429.

2. Hosseini E. Experimental investigation of effect of asphaltene deposition on oil relative permeability, rock wettability alteration, and recovery in WAG process. Petroleum Science and Technology, 2019, vol. 37, Iss. 20, pp. 2150-2159.

3. Moradi M., Shamloo A., Dezfuli A.D. A sequential implicit discrete fracture model for three-dimensional coupled flowgeomechanics problems in naturally fractured porous media. Journal of Petroleum Science and Engineering, 2017, vol. 150, pp. 312-322.

4. Xiong Y., Winterfeld P.H., Wu Y.-S., Huang Z. Coupled geomechanics and pore confinement effects for modeling unconventional shale reservoirs. Unconventional Resources Technology Conference. Denver, United States, 2014. DOI: 10.15530/urtec-20141923960.

5. Antonellini M., Cilona A., Tondi E., Zambrano M., Agosta F. Fluid flow numerical experiments of faulted porous carbonates, Northwest Sicily (Italy). Marine and Petroleum Geology, 2014, vol. 55 , pp. 186-201.

6. Wilson T.H., Smith V., Brown A. Developing a model discrete fracture network, drilling, and enhanced oil recovery strategy in an unconventional naturally fractured reservoir using integrated field, image $\log$, and three-dimensional seismic data. AAPG Bulletin, 2015, vol. 99, Iss. 4, pp. 735-762.

7. Feng Z., Shuhong W. Fully coupled hydromechanical flow simulation of water -induced dynamic fractures in low-permeability res- ervoirs. International Field Exploration and Development Conference, IFEDC 2016. Beijing, China, 2016. Iss. CP706.

8. Kashnikov Yu.A., Ashikhmin S.G., Shustov D.V., Yakimov S.Yu., Kukhtinskii A.E. Increasing efficiency of hydrocarbon fields development based on complex geomechanical research. Oil Industry, 2019, no. 3, pp. 66-69. In Rus.

9. Lebedynets N.P. About deformation changes of fractured reservoirs permeability. Oil Industry, 2014, no. 6, pp. 99-101. In Rus.

10. Gladkikh E.A., Khizhnyak G.P., Galkin V.I. Influence of filtration-capacitive properties of development objects on the value of oil displacement efficiency in various geological and physical conditions. Bulletin of the Tomsk Polytechnic University. Geo Assets Engineering, 2018, vol. 329, no. 7, pp. 77-85. In Rus.

11. Mahzari P., Jones A.P., Oelkers E.H. An integrated evaluation of enhanced oil recovery and geochemical processes for carbonated water injection in carbonate rocks. Journal of Petroleum Science and Engineering, 2019, vol. 181, Iss. no. 106188.

12. Zanganeh B., Soroush M., Williams-Kovacs J.D., Clarkson C.R. Parameters affecting load recovery and oil breakthrough time after hydraulic fracturing in tight oil wells. Unconventional Resources Conference. Calgary, Canada, 2015. No. SPE-175941-MS.

13. Islam A., Ziarani A.S., Cui A., Ehlers S., Schneider B. Experimental and analytical core and geomechanical data analysis of a tight oil carbonate formation. Proceedings. SPE Annual Technical Conference and Exhibition. Amsterdam, Netherlands, 27-29 October 2014. Vol. 6, pp. 4772-4792.

14. Shcherbakov A.A., Khizhnyak G.P., Galkin V.I. Prediction of sidetrack wells productivity index (on example of the Unvinskoe field). Bulletin of the Tomsk Polytechnic University. Geo Assets Engineering, 2019, vol. 330, no. 5, pp. 93-99. In Rus. 
15. Poplygin V.V., Wiercigroch M., Pavlovskaia E.E. Forecasting changes of the wells productive coefficients for the BashkirianSerpukhovian deposits in the north of the Perm region. Oil Industry, 2016, no. 10, pp. 78-81. In Rus.

16. Buzinov S.N., Umrikhin I.D. Gidrodinamicheskie metody issledovaniya skvazhin i plastov [Hydrodynamic methods for the study of wells and reservoirs]. Moscow, Nedra Publ., 1973. 248 p.

17. Mordvinov V.A., Poplygin V.V., Sidorenko D.D., Shaymardanov A.R. Wells productivity after acid fracturing in the Gagarinskoye and Ozernoye oilfields. Oil Industry, 2013, no. 4, pp. 44-45. In Rus.

18. Jahani N., Haugen B., Berge G. Coupled fluid flow and elastoplastic damage analysis for fractured porous chalk with induced wormhole. International Journal of Rock Mechanics and Mining Sciences, 2015, vol. 80, pp. 129-136.

19. Pavlovskaia E., Poplygin V.V., Ivanov D.Yu., Eliseyev I.Yu. Effectiveness of acidizing in Bashkir deposits of Perm Region. Oil Industry, 2015, no. 3, pp. 28-30. In Rus.

20. Martyushev D.A. Laboratory studies of acid compositions for treating reservoir, characterized by various carbonate content and void structure of rocks. Bulletin of the Tomsk Polytechnic University. Geo Assets Engineering, 2018, vol. 329, no. 4, pp. 6-12. In Rus.

Received: 12 March 2020.

Information about the authors

Vladimir V. Poplygin, Cand. Sc., associate professor, Perm National Research Polytechnic University. Aleksandr V. Sokolov, engineer, LUKOIL-Engineering LLC-PermNIPIneft. 